\title{
USING PUPPET MEDIA IN IMPROVING THE SPEAKING ABILITY OF JUNIOR HIGH SCHOOL STUDENTS 4 WARU SIDOARJO
}

\author{
Dwi Nur Hadiyansah \\ English lecturer, Social and Humanities, Ibrahimy University, Indonesia \\ Corresponding Author Email: dwinurhadiyansah@ibrahimy.ac.id
}

\section{A B S T R A C T S}

To improve student achievement in EFL English, it was necessary and urgent to implement the model of innovative learning and constructive learning was through monologues that used this doll property. Property dolls were used to increase student motivation and provide a different atmosphere in learning to talk (speaking). Since all knowledge, dexterity, and skills had practical value. By obtaining the three men would more easily meet the desired of development. The important lesson here was not that we can achieve through the lesson. The subjects of this study were the $7^{\text {th }}$-grade student of Junior high school in Waru Sidoarjo. Classroom Action Research was designed in 2 cycles, respectively - each cycle consisting of the planning, execution, observation, and reflection. Research instrument and its action plan (teaching materials, observation sheets, and questionnaires) prepared by the researcher. The resulted in the first cycle based on observations. The evidence in the first cycle was not completed by 10 students or $25 \%$, and a total of 30 students or $75 \%$. These data show that the first cycle was not finished in the classical method as the standard was $85 \%$. While the results of descriptive monologue presentations on the second cycle value - an average 81.75, while in the first cycle was 75.9. From these data, there was an increase of 5.85. Thus, the results obtained were consistent with the hypothesis proposed action, namely the use of appropriate doll media can improve the ability to speak in descriptive monologues for EFL.

\begin{tabular}{l}
\hline A R T I C L E I N F O \\
\hline Article History: \\
Received: October, 2020
\end{tabular}

Revised: November, 2020

Published: December, 2020

Keywords:
Descriptive Monologue,
Speaking performance,
Doll Media,
EFL,

Keywords:

Doll Media

How to cite: Hadiyansah, D. (2020). Using Puppet Media in Improving the Speaking Ability of Junior High School Students 4 Waru Sidoarjo. Jo-ELT (Journal of English Language Teaching) Fakultas Pendidikan Bahasa \& Seni Prodi Pendidikan Bahasa Inggris IKIP, 7(2), 74-88. doi:https://doi.org/10.33394/joelt.v7i2.3146

\section{INTRODUCTION}

Communication is a way to provide and obtain information. To get the information we use Language to reveal our identity, our character, and our background. (Dwi, 2014) Language is an important aspect of human life, used to communicate with others. The language also plays an important role in students' intellectual, social, and emotional development. therefore, learning languages is essential to help students to express their ideas, feelings, social interactions, and analyze students' imagination skills (Hasanah, 2019).

When every student can speak English, it will provide knowledge and skills as a means of communication. English as an international language needs to be improved. The improvement in English learning must be visible so that the quality of students' language proficiency has certain abilities. The proficiency itself includes mastery of written and spoken language. This is explained by (Yolanda \& Hadi 2019) which states that English is taught in every school starting from kindergarten until high school. And also, as a compulsory course at universities in Indonesia. 
One of the main problems in the learning of language in school is the low absorption of students. It seems that the average student's learning outcomes in English are very worrying. This achievement is certainly the result of conventional learning conditions and does not touch the realm of the learner dimension. Empirically, on the other hand, based on the analysis of the resulting study of low student learning outcomes, it became worse because the learning process is dominated by traditional learning. In a learning-centered classroom atmosphere, teachers tend to be passive listeners. (Yolanda \& Hadi 2019) states that English teachers teach students speaking skills with vocab repetition and also teach to memorize dialogue to speak English well. It is also supported by Rusyani (Dwi, 2018) most of them say that learning the language is very difficult, this is because 1. It's hard to express what we think; 2. Cultural differences in greeting or self-introduce; 3. The difficulty of writing the way we want; 4. Difficulty in answering the teacher's question; 5. Difficulty in speaking with good and true sentences. The above facts also occur to EFL students in the speaking material. At the time the learning process occurs most students do not pay attention; concentration is low and some students are sleepy. This resulted to make a decrease in learning outcomes in English speaking subjects.

To improve the achievement of students in English classes, it is necessary to implement innovative learning models and that was conducive to learning. Students are more likely to learn lessons in an active state, where students can learn together by interacting with their friends, with their teachers, or with their families in a fun environment (Tamah, 2011). Using puppet media is one alternative in Language learning, this can be categorized as the best way because it can make them happy (Setiawati, 2016). Puppet media can keep students interested and involved not only in learning materials but also in learning knowledge and deeds in onepiece (Blatner, 2009) Puppet media is used to increase students' motivation and provide a different atmosphere in learning to speak English because it can develop the knowledge, dexterity, and skills. By acquiring these three things people will more easily develop their speaking skills in English. (Brown, 2001) role-playing involves both students in the division of roles to one or more in a group and assigns a task to be completed. Brown suggests role playing can be done with one person (using dolls), in pairs, or in groups where each person plays a character. This is also said by (Harmer, 2007) the use of media in the learning process of teaching provides positive values. Role playing is a method of exploring ideas which involving complex social situations that are likely to be used in literature classroom, history, and natural sciences (Blatner, 2007).

Setiawati (2016), also conducted similar research, the difference with this study is in the variables. In Setiawati's research, she used media to improve the vocabulary of students while in this study were more interested in improving students' speaking abilities. Similar things are also done by (Made, 2019) It's explained in her research, she's more interested in using the puppet media for childhood education. And the same thing is done by (Peristiwandari, 2012), (Nuruzzakaria, 2016), (Bhima, 2019), (Hayatun, 2018), (Yolanda and Hadi 2019), (Bakhsh, 2016), (Hasanah, 2019) which uses media like dolls in its research. The difference is on the finding between each other that most of them differ on their variable and place. A fundamental problem in this study was the difficulty of students in expressing their verbal language skills. So, learning media is needed to improve their speaking skills. it going to use puppet media to improve the speaking skills of EFL students.

\section{RESEARCH METHOD \\ Research Design}

This study is used the Class Action Research method, it uses a cycle process that adapted from the model in which Kemmis and Mc- Taggart cited Koshy (2005). It can be 
seen in the CAR Model Figure covering a cycle consisting of four steps, namely planning, implementation, observation, and reflection. The cycle is carried out until it reaches the criteria of success.

Table 1

Research Procedure Cycle I

\begin{tabular}{cll}
\hline \multicolumn{1}{c}{ Action } & \multicolumn{1}{c}{ Description } \\
\hline 1. Provide descriptive text & $\begin{array}{l}\text { Teachers provide an example of descriptive } \\
\text { text as a reference for students to create } \\
\text { their texts with different titles. }\end{array}$ \\
\hline 2. Create texts in groups & $\begin{array}{l}\text { Students create texts in groups of students to } \\
\text { discuss and provide feedback to produce } \\
\text { good text. }\end{array}$ \\
\hline 3. Improve the level of the text & $\begin{array}{l}\text { Once students have finished creating text in } \\
\text { groups, it makes a good improvement in the } \\
\text { use of words and sentences }\end{array}$ \\
\hline 4. Determined the topic & $\begin{array}{l}\text { In the creation of individual text, the topic } \\
\text { needs to be determined. While the selected } \\
\text { topic is a description of a person or } \\
\text { something. }\end{array}$ \\
\hline 6. $\quad$ Make a text & $\begin{array}{l}\text { Make the text done by the student' itself at } \\
\text { home as homework. }\end{array}$ \\
\hline 7. Apply the descriptive text & $\begin{array}{l}\text { Teachers give students time to consult their } \\
\text { work. }\end{array}$ \\
\hline
\end{tabular}

While performing the actions, carried out observations of student behavior associated with a given action can be detected by observing the extent to which changes to student behavior when compared before given the action. Thus, it can be seen behavioral changes that indicate the creation of student interest and motivation, especially in descriptive monologues. It can also be known whether the implementation of actions by what was planned. Observations were made in various ways, namely, assessment of student performance, charge sheet observation by the observer, and student assessment results to show her friends. This was done to obtain data on the behavior of students in the learning process associated with a given action. Besides, to find out the results obtained values of students, to measure improvements in student learning outcomes. 
Table 2

Research Procedure Cycle 2

\begin{tabular}{cll}
\hline \multicolumn{1}{c}{ Action } & \multicolumn{1}{c}{ Description } \\
\hline 1. Make a U-shape & $\begin{array}{l}\text { Make a cycle of U-shaped arrangement of the } \\
\text { bench was changed so that there are differences } \\
\text { in an atmosphere that is expected to increase } \\
\text { students' motivation. }\end{array}$ \\
\hline 2. Make student on guard & $\begin{array}{l}\text { Turn looks like a gathering of students raffled, } \\
\text { so expect all students are always ready to } \\
\text { perform. }\end{array}$ \\
\hline 3. make the student more active & $\begin{array}{l}\text { Students who have not completed in the } \\
\text { appearance of the cycle I was told to choose one } \\
\text { friend who was chosen to help a friend who has } \\
\text { not been completed to study together and to } \\
\text { give guidance to make the data look better and } \\
\text { be thorough. }\end{array}$ \\
\hline 4. Give the assessment & $\begin{array}{l}\text { Assess the student so that the teacher will know } \\
\text { how far the student developed }\end{array}$ \\
\hline 5. Interviewing the student & $\begin{array}{l}\text { Interview the student after giving them an } \\
\text { assessment so that the teacher will know what } \\
\text { they will and won't do to make their student } \\
\text { better. }\end{array}$ \\
\hline
\end{tabular}

Collaborators and students' responses after the observation selection were done to obtain the data, then the data is processed and analyzed to eventually be used as a basic conclusion. Researchers can discover whether or not held back or continue the study for the next cycle. When the poorer outcomes were unappropriated and the original plan has been established, then the next step to find the factors causing the failure or the failure to achieve the planned targets.

Table 3

Data Collection procedure

\begin{tabular}{ll}
\hline \multicolumn{1}{c}{ Action } & \multicolumn{1}{c}{ Description } \\
\hline & $\begin{array}{l}\text { This assessment sheet is used to assess student } \\
\text { performance on the oral form of a descriptive } \\
\text { 1. Assessment Sheet }\end{array}$ \\
& $\begin{array}{l}\text { monologue delivered by the media puppet. Things } \\
\text { (pronunciation), (Fluency), (performance), and } \\
\text { (creativity). }\end{array}$ \\
\hline 2. Observations & $\begin{array}{l}\text { Observations by researcher and observer, this } \\
\text { observation is to see and observe student behavior } \\
\text { 3. Field Notes }\end{array}$ \\
\hline & $\begin{array}{l}\text { The field contains notes made by investigators } \\
\text { during the action and the observer. }\end{array}$ \\
\hline 4. Input from Collaborators & Collaborators studied the activities of researchers \\
and research activities of students during a class \\
action. Observations will be presented to \\
researchers who will be discussed to make \\
conclusions and determine the next steps.
\end{tabular}

\section{Population and Sample}

The subjects in this study were students of class VII.5 on SMP 4 Waru. It consists of 40 students consisting of 15 male students and 25 female students. This research was conducted 
in the first half of the 2018 to 2019 school year. The study spoke about descriptive monologues using puppet media.

\section{Data Analysis}

Data analysis techniques used are data reduction, data presentation, drawing conclusions, verification of reflection. 1) The reduction of data obtained from observations and questionnaires were written in the form of recorded data, are collected, summarized, and selected the subject, then look for patterns. So the recording of data is material. The data is then arranged more systematically, will find the basic stuff so much sharper. The observation makes the researcher record the data that is obtained when required. 2) Presentation of Data, the data were reduced and grouped in various patterns described in the form of words that are useful to see the whole picture or a particular section. The presentation of this data is written in the exposure data. 3) Conclusion withdrawal, Verification, and Reflection. The data obtained were searched pattern, theme, relationships, or matters that often arise from the data is re-generated while the conclusion is called the findings of researchers. Withdrawal of the findings of research conducted on the conclusion of the indicators of meaning or reflection is then performed to obtain the conclusion. The results do reflect conclusions or to determine the next action plan. formula:

The test results to measure student learning exhaustiveness processed using the

$$
\frac{\sum \text { LastTPK }}{\sum A l l T P K} \times 100 \%
$$

As standard, the thoroughness of student learning are used to set the benchmark by $70 \%$ individually and $85 \%$ completeness in the classical style. This formula is used to determine how much development and improvement of students' speaking descriptive achieved.

Finding Average (Mean)

The formula $\mathrm{M}=\frac{\text { Total }}{\text { Total }} \frac{\text { Score }}{\text { Student }}$

This formula is used to determine the development and improvement of cycle one descriptive speaking with other cycles. While the value of learning in the classical completeness per item valuation is $75 \%$. So if in the classical for the mission (content) is $75 \%$ above the classical completeness is reached.

Table 4

Category of speaking Ability descriptive at class VII.5 SMPN 4 Waru

\begin{tabular}{cc} 
Interval & Criteria for Speaking Ability \\
\hline $91-100$ & Very High \\
$81-90$ & High \\
$70-80$ & Average \\
$60-69$ & low \\
$50-59$ & Very low \\
\hline
\end{tabular}

Research on analytical results are written, analytical approach to the study by speaking into the descriptive aspects or specific categories to be more objective in the assessment. Analysis of the elements of speaking is the (content), (pronunciation), (Fluency), (performance), and (creativity). For practical purposes to determine the weight or size of servings for each element given the same weight based on the level of importance of each 
element in the descriptive speaking. Thus the more important elements are weighted higher. Based on these individual elements are given descriptively speaking a maximum score of 100.

Research speaking descriptive elements, the researchers did was look for a minimum score of students who completed the provision of assessment as a benchmark the average for speaking descriptively as a result.

Formula

$$
\mathrm{R}=\frac{70 x \text { ScoreMaximum }}{100}
$$

$\mathrm{R}=$ Score of at least the students thoroughly.

Table 5

Elements of Assessment of the Maximum score and Minimum score

\begin{tabular}{clcc} 
No. & An Element of The Graded & Score Maximum & Score Minimum \\
\hline 1. & Content & 25 & $>13$ \\
2. & Pronunciation & 20 & $>11$ \\
3. & Fluency & 20 & $>10$ \\
4. & Performance & 20 & $>10$ \\
5. & Creativity & 15 & $>10$ \\
\hline
\end{tabular}

Further reduction of the activities carried out the final inference is then followed by the verification or testing of scientific findings.

\section{RESEARCH FINDINGS AND DISCUSSION \\ Research Findings \\ The first Action Plan}

Initial reflection is carried out by performing preliminary observations to determine the initial conditions conducted by the researcher and observer when teachers implement the teaching and learning process during the two-hour lesson. The results of the analysis of the initial reflection are used to determine the formulation of a plan of action that is the beginning of the learning strategy.

Subsequently, based on the results of reflection can be concluded that students are less skilled in speaking lessons, especially in descriptive monologues.

Speaking of learning activities are presented using descriptive monologue puppet media so that students are more motivated because the activities are fun.

The steps that have been prepared to support the implementation of research or observations to improve the ability to speak to the student. first, it should develop and prepare a syllabus of learning instruments, Leason plan (RPP), observation sheets, and pieces of research, determine the implementation schedule of the study, the first cycle will be conducted in two sessions, with the details of each meeting of 2 x 40 minutes (two periods), prepare students for research by asking students to prepare a monologue of descriptive text, home study and prepare the doll media, determine the theme of descriptive text, which describes someone or something, preparing students to be used to assess his form of pieces of paper the size of $5 \times 10 \mathrm{~cm}$ which will be used to assess five of his friends and determine the best performance among these five, preparing a microphone (speakers) to be used for presentations. 
Before entering the first cycle of these, students have passed the specific exam. On the cycle, the researcher was a late stage of ICOT (Individual Construction of Text) are presented with descriptive text media puppet. This presentation is a descriptive monologue, dialogue with the students to describe one's doll or something.

Students speak by themselves and also acts like a doll (representing talking doll). So every student prepares two different sounds. While the presentation, teachers or researchers in their evaluation. Things that are judged are content, pronunciation, fluency, performance, and creativity. The score is given to the Content (25), Pronunciation (20), Fluency (20), Performance (20), and Creativity (15).

Students who make observations and used as a jury to choose is the best student among every five performances. The way a safety sheet/assessment that contains the selected five of his friends one of the best score a minimum 60 and maximum value of 100 . After the sheet is completed, the next sheet is replaced until all students are performing. So that at the end of the presentation was announced eight best students dressed audience preferred version. And for those who are selected will be called to the front of the class, being congratulated by the teacher and get a prize.

$\left.\begin{array}{|ll}\hline \text { 1. Rusnati } & 70 \\ \text { 2. Marlon } & 80 \\ \text { 3. Sarah } & 75 \\ \text { 4. Wahab } & 60 \\ \text { 5. Yuna } & 90\end{array}\right\} \quad$ winner: Yuna

Figure 1. Examples of assessment

\section{The implementation of the Action-1}

The implementation of measures to be implemented-1 with a plan, to improving the ability to speak a monologue in the form of descriptive.

Cycle I consists of two meetings, with each meeting 2 x 40 minutes.

Actions were taken at each cycle. In cycle 1 make each student is ready to perform monologues descriptive presentation using puppet media, and then performed sequentially turn called by the number absent, another student was given the job to be a judge who participated assess his performance, the teachers share pepper to place judgment, valuation range is 60-100 to evaluate the student, every five times the appearance asked a classical teacher, who is performing best and then record it. Students are given support and applause to cheer his friend who appeared, either before the presentation or after the presentation. researchers give judgment by the assessment form that has been prepared which consists of assessment content, fluency, pronunciation, appearance, and creativity, and the observer helps smooth the research primarily on classroom management and provide observations on the course of learning during research action takes place.

\section{Observations Action in Cycle-1}

Based on observational data after a given action on a cycle, the research can reveal changes in the student changes. Teachers should try to help the student by learning to use the media puppet speaking to motivate the students so they can develop a description that made more extensive and can talk more. Make student courage growing, as evidenced by their appearance to talk while demonstrating the movement of time talking doll. Tasks are assigned to assess his students that appear to make them pay attention to his appearance. Students look bored because often saw the appearance of a cute friend.

In addition to the above research results obtained by students after participating in the learning process by applying the doll media can be determined whether a descriptive 
monologue speaking doll by using media to enhance the ability of students in grade VII SMPN 4 Waru.

From the observation results of the assessment can serve researchers speaking descriptive monologue on the cycle I in table 6.

Table 6

Capability Assessment Descriptive Monologue Speaking with the doll Media cycle -1

\begin{tabular}{|c|c|c|c|c|c|c|c|c|}
\hline No & Name of student & $\begin{array}{c}\text { Content } \\
\text { (25) }\end{array}$ & $\begin{array}{c}\text { Pronunciation } \\
\text { (20) }\end{array}$ & $\begin{array}{c}\text { Fluency } \\
\text { (20) }\end{array}$ & $\begin{array}{l}\text { Performance } \\
\text { (20) }\end{array}$ & $\begin{array}{c}\text { Creativity } \\
\text { (15) }\end{array}$ & $\begin{array}{l}\text { Total } \\
\text { Score }\end{array}$ & Summary \\
\hline 1 & Austina & 15 & 12 & 12 & 12 & 10 & 61 & No \\
\hline 2 & Alfin & 15 & 14 & 13 & 13 & 12 & 67 & No \\
\hline 3 & Aqidatul & 16 & 12 & 12 & 12 & 10 & 62 & No \\
\hline 4 & Aulia & 23 & 15 & 13 & 19 & 14 & 84 & Yes \\
\hline 5 & Ayu & 20 & 12 & 15 & 15 & 12 & 74 & Yes \\
\hline 6 & Ayu Selly & 15 & 12 & 12 & 12 & 10 & 61 & No \\
\hline 7 & Bagus & 21 & 16 & 15 & 19 & 13 & 84 & Yes \\
\hline 8 & Bagus Setya & 15 & 12 & 12 & 12 & 10 & 61 & No \\
\hline 9 & Bintari & 23 & 16 & 18 & 17 & 14 & 88 & Yes \\
\hline 10 & Dia & 20 & 14 & 14 & 12 & 11 & 71 & Yes \\
\hline 11 & Diana & 22 & 15 & 15 & 12 & 13 & 79 & Yes \\
\hline 12 & Dita & 23 & 18 & 19 & 18 & 12 & 90 & Yes \\
\hline 13 & Dita Ari & 20 & 16 & 16 & 17 & 13 & 82 & Yes \\
\hline 14 & Doddy & 15 & 13 & 14 & 15 & 10 & 67 & No \\
\hline 15 & Ernesto & 17 & 13 & 14 & 14 & 12 & 70 & Yes \\
\hline 16 & Fidya & 24 & 18 & 17 & 19 & 13 & 91 & Yes \\
\hline 17 & Genemart & 15 & 15 & 15 & 15 & 12 & 72 & Yes \\
\hline 18 & Guruh & 20 & 15 & 15 & 12 & 9 & 71 & Yes \\
\hline 19 & Haris & 22 & 17 & 16 & 18 & 12 & 85 & Yes \\
\hline 20 & Harmadi & 15 & 15 & 12 & 15 & 10 & 67 & No \\
\hline 21 & Hasril & 22 & 17 & 16 & 17 & 14 & 86 & Yes \\
\hline 22 & Herlambang & 15 & 15 & 15 & 15 & 10 & 70 & Yes \\
\hline 23 & Intan & 23 & 18 & 18 & 17 & 14 & 90 & Yes \\
\hline 24 & Khabibul & 20 & 15 & 16 & 18 & 12 & 81 & Yes \\
\hline 25 & M. Khoirul & 15 & 15 & 15 & 15 & 10 & 70 & Yes \\
\hline 26 & M. Mukharrabin & 16 & 15 & 14 & 16 & 13 & 74 & Yes \\
\hline 27 & Marlinda & 20 & 17 & 18 & 19 & 14 & 88 & Yes \\
\hline 28 & Nasir & 15 & 12 & 12 & 12 & 10 & 61 & No \\
\hline 29 & Nisyadea & 22 & 16 & 16 & 18 & 14 & 86 & Yes \\
\hline 30 & Nurul & 20 & 17 & 17 & 18 & 13 & 89 & Yes \\
\hline 31 & Okky & 22 & 18 & 18 & 18 & 15 & 90 & Yes \\
\hline 32 & Ovitya & 15 & 15 & 15 & 13 & 10 & 68 & No \\
\hline 33 & Permata & 21 & 18 & 18 & 18 & 15 & 90 & Yes \\
\hline 34 & Putri & 23 & 17 & 17 & 18 & 14 & 89 & Yes \\
\hline 35 & Rhanita & 23 & 16 & 16 & 16 & 13 & 84 & Yes \\
\hline 36 & Rismana & 16 & 15 & 15 & 15 & 13 & 74 & Yes \\
\hline 37 & Rizka & 20 & 15 & 15 & 15 & 14 & 79 & Yes \\
\hline 38 & Reza & 15 & 12 & 12 & 13 & 10 & 62 & No \\
\hline 39 & Tiurma & 17 & 16 & 15 & 15 & 12 & 75 & Yes \\
\hline \multirow[t]{4}{*}{40} & Febri & 15 & 12 & 12 & 12 & 10 & 61 & No \\
\hline & Total Score & 751 & 601 & 599 & 619 & 479 & \multirow[t]{3}{*}{76,7} & \multirow[t]{3}{*}{ Average } \\
\hline & Maximal Score & 1000 & 800 & 800 & 800 & 600 & & \\
\hline & Score \% & $75 \%$ & $74,8 \%$ & $74,8 \%$ & $77 \%$ & $79 \%$ & & \\
\hline
\end{tabular}

From table 6, it can be seen the Capability Assessment Descriptive Monologue Speaking with the doll Media cycle-1. The researcher divided the subjective into 5 categories which are Content, Pronunciation, Fluency, Performance and Creativity. And then the 
researcher shows the value of the student from the lowest until the highest. There is 13 student with the lowest value in content subject with 15 points. And only 1 person with the highest point with 24 points. In pronunciation subject, there is 8 student with the lowest value which is 12 point. And 5 students in the highest value which is 18 points. Next is fluency subject which has 8 students in the lowest value which is 12 points. And only 1 student with 19 points which is the highest value in fluency subject. The performance subject also has the lowest point in 12 and it is from 9 students, while their highest point is in 19 from 4 students. The last subject is creativity, it has 8 students with 12 points which is the lowest point and 2 students with 15 points for the highest point.

Table 7

Frequency Distribution pre-test I Speaking Ability Descriptive Monologue With The Process of Learning Using The Doll Media

\begin{tabular}{cccc}
\hline Interval Class & Frequency & Criteria & Percentage \\
\hline $91-100$ & 1 & Very high & $2,5 \%$ \\
$81-90$ & 16 & High & $40 \%$ \\
$70-80$ & 12 & Average & $30 \%$ \\
$60-69$ & 11 & Low & $27,5 \%$ \\
$50-59$ & 0 & Very low & $0 \%$ \\
\hline Total & 40 & & $100 \%$ \\
\hline
\end{tabular}

From table 7 it can be presented analysis assessment criteria and achievement of completeness. The level of content reached $75 \%$. This indicates that the student has understood the content of the descriptive text to be delivered. And completeness in the classical style has been reached. The level of pronunciation reached $74.8 \%$. Completeness in the classical meaning has not been reached so that a need for exercise to say the words (vocabulary) appropriate for a descriptive study. The level of fluency reached $74.8 \%$. This shows that the completeness in the classical style has not been achieved. Students should prepare by practicing at home before the presentation. The level of performance reached $77 \%$, meaning that the completeness in the classical style has been reached. The level of creativity reached $79 \%$. Completeness means that the classical style of learning has been achieved. And indicates that the student is quite creative.

The data value frequency distribution of descriptive monologue speaking skills in the learning process that uses a puppet media can be summarized as Descriptive monologue speaking ability levels who obtain very high criteria there are 1 student and reach a percentage of $2,5 \%$, descriptive monologue speaking ability levels who obtain high criteria there were 16 students and reach a percentage of $40 \%$, descriptive monologue speaking ability levels who obtain average criteria there were 12 students and reach a percentage of $30 \%$, descriptive monologue speaking ability levels who obtain high criteria there were 11 students and reach a percentage of $27,5 \%$, there are no student whose the value is very low.

The results of his research students to the appearance of eight people selected the best students dressed in speaking the next lesson they called "The best performance eight" in cycle I, namely: 1) Aulia Gheasari, 2) Binary Atmanegara, 3) Dita Anggraeny Permatasari, 4) Fiya Ayu Safitri, 5) Intan Mustika Wati, 6) Nisyadea Bachara Putri, 7) Permata Putri Ismah Ariani, 8) Rizka Primadita Wardani. They called to the front of the class to get the congratulations and gifts.

\section{The Reflection of Cycle -1}

Based on the data analysis of student achievement in learning descriptive monologue speaking with the media puppets can be concluded that the cycle of learning in the classical completeness I've reached $85 \%$. But several things still need improvement include: a) The 
use of simple present tense is still not quite right, b) Contents in descriptive monologues delivered by the students, most of which are less precise and there is still need the example, c) Seating positions of students need to be modified to avoid monotony, d) There are still some students who aren't different two sounds, e) Some students are less prepared for presentation, need to be assisted by a friend who idolized, f) Some students do not bring their dolls so it appears less than the maximum, g) At the time of the doll can turn to speak (represented by the students themselves) doll is not moved. The things mentioned above will be fixed in the second cycle of action.

\section{The action of Plan -2}

The preparation of the second cycle at a meeting or two-hour lesson. On the occasion of two hours was used to prepare the things to be done on the second cycle. Actions carried out based on these cycle deficiencies specified in the activity of cycle I. Deficiencies that occur in the cycle I that the student should not use simple present tense which is still not quite right. contents in descriptive monologues delivered by the students, most of which are less precise and there is still need an example, seating positions of students need to be modified to avoid monotony, there are still some students who are not two different sounds, some students are less prepared for the presentation, some students do not bring their dolls, so it appears less than the maximum, at the time the doll can turn to speak (represented by the students themselves) doll is not moved. There are also the steps which taken by researchers to correct these deficiencies: Tell us about the form of simple sentences in the present tense or present tense, and students are trained to use it, the teacher gives an example (modelling) of a descriptive monologue by using puppets, namely: Open with a greeting (greetings) to greet classmates, delivering the content of the dialogue in which there is a descriptive element, which describes someone or something of the existing deficiencies in the cycle I, then that will be done later in this cycle are: change seating positions of students in half circle to give a more fresh than usual, students whose value has not been fully prepared to choose a friend that I idolized in the performance cycle, then the teacher asked the boy who idolized them to teach or study together for the next monologue presentation, expected of all students bring their dolls, expected of all students using two different voices, one for himself to another for her dolls, at the time explaining the doll was telling you, the doll is moved, to be clearer about who is talking, closed by the cover, for example: Ok friend, that's all, thank you for your attention. see you ...

\section{Implementation of the Action at the Cycle-2}

Actions are taken by the planning cycle to improve the student's skills in basic competencies speaking primarily descriptive monologue using the media puppets.

Cycle II consists of two meetings, or 2 x 2 -hour lesson, with the implementation of the following: the teacher started the lesson by opening activities, the seating position is transformed into a half-circle, students who have graduated have been guided by other student idolized, all students have brought their dolls, teachers have been preparing lots for determining the appearance of a turn, the teacher has prepared complete assessment sheets relating to the content, pronunciation, fluency speech, appearance, and creativity, also, be prepared to be used by students to assess their friends to determine the best performance.

\section{Observations in the Cycle-2}

The observation can present the results of the study investigators descriptive monologue speaking in the second cycle in table 8. 
Table 8

Capability Assessment Descriptive Monologue Speaking with the doll Media cycle

\begin{tabular}{|c|c|c|c|c|c|c|c|c|}
\hline No & Name of student & $\begin{array}{c}\text { Content } \\
\text { (25) }\end{array}$ & $\begin{array}{c}\text { Pronunciation } \\
\text { (20) }\end{array}$ & $\begin{array}{c}\text { Fluency } \\
\text { (20) }\end{array}$ & $\begin{array}{l}\text { Performance } \\
\text { (20) }\end{array}$ & $\begin{array}{c}\text { Creativity } \\
\text { (15) }\end{array}$ & $\begin{array}{l}\text { Total } \\
\text { Score }\end{array}$ & Summary \\
\hline 1 & Austina & 20 & 17 & 16 & 17 & 14 & 84 & Yes \\
\hline 2 & Alfin & 18 & 14 & 16 & 14 & 13 & 75 & Yes \\
\hline 3 & Aqidatul & 20 & 14 & 15 & 17 & 13 & 79 & Yes \\
\hline 4 & Aulia & 24 & 17 & 18 & 17 & 14 & 90 & Yes \\
\hline 5 & Ayu & 19 & 17 & 15 & 16 & 12 & 79 & Yes \\
\hline 6 & Ayu Selly & 18 & 15 & 14 & 13 & 12 & 72 & Yes \\
\hline 7 & Bagus & 20 & 15 & 15 & 16 & 14 & 80 & Yes \\
\hline 8 & Bagus Setya & 18 & 15 & 16 & 16 & 13 & 78 & Yes \\
\hline 9 & Bintari & 21 & 16 & 16 & 17 & 14 & 84 & Yes \\
\hline 10 & Dia & 21 & 14 & 14 & 12 & 11 & 72 & Yes \\
\hline 11 & Diana & 20 & 14 & 14 & 14 & 13 & 76 & Yes \\
\hline 12 & Dita & 21 & 17 & 17 & 17 & 14 & 86 & Yes \\
\hline 13 & Dita Ari & 21 & 16 & 16 & 17 & 13 & 83 & Yes \\
\hline 14 & Doddy & 18 & 16 & 16 & 16 & 13 & 79 & Yes \\
\hline 15 & Ernesto & 17 & 14 & 14 & 15 & 12 & 72 & Yes \\
\hline 16 & Fidya & 21 & 17 & 17 & 18 & 14 & 87 & Yes \\
\hline 17 & Genemart & 15 & 12 & 12 & 12 & 10 & 61 & No \\
\hline 18 & Guruh & 18 & 15 & 16 & 13 & 12 & 74 & Yes \\
\hline 19 & Haris & 21 & 16 & 17 & 17 & 13 & 84 & Yes \\
\hline 20 & Harmadi & 20 & 17 & 15 & 16 & 13 & 81 & Yes \\
\hline 21 & Hasril & 18 & 16 & 16 & 15 & 13 & 78 & Yes \\
\hline 22 & Herlambang & 20 & 16 & 16 & 16 & 13 & 81 & Yes \\
\hline 23 & Intan & 22 & 18 & 19 & 16 & 15 & 90 & Yes \\
\hline 24 & Khabibul & 18 & 17 & 16 & 18 & 13 & 82 & Yes \\
\hline 25 & M. Khoirul & 18 & 15 & 16 & 13 & 12 & 74 & Yes \\
\hline 26 & M. Mukharrabin & 17 & 16 & 17 & 16 & 13 & 79 & Yes \\
\hline 27 & Marlinda & 22 & 17 & 17 & 19 & 14 & 89 & Yes \\
\hline 28 & Nasir & 15 & 12 & 12 & 12 & 12 & 63 & No \\
\hline 29 & Nisyadea & 24 & 19 & 18 & 16 & 13 & 90 & Yes \\
\hline 30 & Nurul & 20 & 17 & 16 & 17 & 14 & 84 & Yes \\
\hline 31 & Okky & 21 & 17 & 16 & 18 & 14 & 86 & Yes \\
\hline 32 & Ovitya & 18 & 16 & 16 & 15 & 13 & 78 & No \\
\hline 33 & Permata & 22 & 18 & 18 & 18 & 15 & 91 & Yes \\
\hline 34 & Putri & 21 & 18 & 18 & 19 & 15 & 91 & Yes \\
\hline 35 & Rhanita & 20 & 15 & 16 & 17 & 14 & 82 & Yes \\
\hline 36 & Rismana & 19 & 16 & 16 & 16 & 13 & 80 & Yes \\
\hline 37 & Rizka & 20 & 16 & 16 & 17 & 13 & 82 & Yes \\
\hline 38 & Reza & 17 & 14 & 12 & 12 & 13 & 68 & No \\
\hline 39 & Tiurma & 20 & 16 & 15 & 16 & 13 & 80 & Yes \\
\hline \multirow[t]{4}{*}{40} & Febri & 18 & 15 & 14 & 14 & 12 & 73 & Yes \\
\hline & Total Score & 782 & 632 & 629 & 630 & 524 & 79,9 & Average \\
\hline & Maximal Score & 1000 & 800 & 800 & 800 & 600 & & \\
\hline & Score $\%$ & $78,2 \%$ & $79 \%$ & $78,6 \%$ & $78,7 \%$ & $87,4 \%$ & & \\
\hline
\end{tabular}

From table 8, the analysis can be exposed to the assessment criteria and achievement of completeness as follows: level of (content) reached $78.2 \%$. This indicates that the student has understood the content of the descriptive text to be delivered in the classical style and thoroughness has been achieved, the level of (pronunciation) reached $79 \%$. Mean completeness in the classical style has been reached, the level of (Fluency) reached $78.6 \%$. This study shows that the completeness in the classical style has been reached, the level of (performance) reached $78.7 \%$, meaning that the completeness in the classical style has been 
reached, the level of (creativity) reached $87.4 \%$. Completeness means that the classical style of learning has been achieved and shows that students are quite creative.

The data obtained from table 8 of the assessment of student ability in cycle 2 can be made into a frequency distribution table in table 9.

Table 9

Frequency Distribution post-test II Speaking ability Descriptive monologue with the process of learning using the doll Media

\begin{tabular}{cccc}
\hline Interval Class & Frequency & Criteria & Percentage \\
\hline $91-100$ & 2 & Very high & $5 \%$ \\
$81-90$ & 17 & Height & $42,5 \%$ \\
$70-80$ & 18 & Average & $45 \%$ \\
$60-69$ & 3 & Low & $7,5 \%$ \\
$50-59$ & 0 & Very low & $0 \%$ \\
\hline Total & 40 & & $100 \%$ \\
\hline
\end{tabular}

From table 9, it can be summarized as follows: descriptive monologue speaking ability levels who obtain very high criteria there are 2 students and percentage of $5 \%$, descriptive monologue speaking ability levels who obtain high criteria there are 17 students and percentage of $42,5 \%$, descriptive monologue speaking ability levels who obtain average criteria there are 18 students and percentage of $45 \%$, descriptive monologue speaking ability levels who obtain low criteria there were 3 students and percentage of 7,5\%, descriptive monologue speaking ability levels who obtain very low criteria doesn't exist, and percentage of $0 \%$. In speaking with the puppets, descriptive monologue on-2 cycle to achieve completeness in the classical act is as high as $95 \%$.

Student assessment of the performance of his elected eight people with the best performance, namely: 1) Aulia Gheasari, 2) Bintari Atma Negara, 3) Fidya Ayu Safitri, 4) Intan Mustika Wati, 5) Nisyadea Bachara Putri, 6) Okky Arisandy S., 7) Permata Putri Ismah Ariani, 8) Putri Ayu Wulandari.

At this time there is the appearance of two students who got the best-looking assessment of the achievement of this descriptive monologue, which is Okky Arisandy $\mathrm{S}$ and Putri Ayu Wulandari. Of the eight students are researchers gave the highest value for the Putri Ayu Wulandari, because also she can speak fluently, she can animate to amaze the audience (other students). Eight students were given a gift of congratulations and sweets. From the results of student, questionnaires can be concluded that learning to use the media puppets speaking quite effective for improving students' abilities.

\section{The Reflection Cycle-2 results}

From the analysis of data on the level of descriptive monologue speaking with the media and the acquisition of dolls and the average level of completeness of students in the second cycle of the increase occurred. Thus it can be concluded that through the application of speaking ability use of the doll media at class VII.5 SMPN 4 Waru be increased.

\section{The finding that occurs in the first cycle}

During the action and observation of one conducted by researchers, found that the following matters: the first cycle on most students still seem undecided in the learning process is hindered and takes a long time to explain things that are still in doubt. Learning conditions and problems that occur students at grade VII.5 SMP 4 Waru that is most difficult to speak the English language (speaking), so take a medium of learning that can enhance their ability to speak. Class conditions there are still many students who are busy, indifferent, roads to and fro, and some students are sleepy. 


\section{Troubleshooting efforts in finding a place in the Cycle I}

To improve student motivation and learning outcomes in speaking of material, then the efforts of researchers after finding deficiencies that occur in the first cycle is: Briefed again about the matter in greater detail the procedures and provide an opportunity to ask something that does not understand the material in cycle I. Enhance and direct how the correct steps to learn how to improve speaking skills with the media puppets descriptive monologues. Cooperative approach, for students who are lazy and less creative in the following English language learning. For example, motivates that English is very useful for their future and provides a solution for why it is difficult to present a descriptive monologue speaking use the doll media. Streamline group collaboration by combining brilliant student peer tutors and students who are low achievement, so that cooperation is established, take care in completing the task. Students have difficulty in forming words, to overcome the second cycle is used before the presentation made the communicative approach, so the students know in advance a wide range of subject vocabulary to be used.

\section{Cycle II}

Presentation of the results of descriptive monologue in the second cycle the average value of 81.75 while in the cycle I was 75.9. From these data, there is a gain of 5.85. Thus the results obtained are consistent with the hypothesis proposed action, namely the use of appropriate media dolls can improve the ability to speak in descriptive monologues VII.5 grade students of SMP 4 Waru.

\section{The finding that occurs in the second cycle}

During the actions and observations made to the two researchers, found that the following matters: a) In general, the second cycle students are encouraged more creative because they create the food and beverage whose name is up to students to be more challenging and interesting, b) Conditions and problems in the second cycle of learning that occur on grade VII.5 SMP 4 Waru most students can speak the English language. c) Classroom conditions are conductive, there are one or two students who do not bother. But in the classical style is conducive.

\section{Troubleshooting efforts in finding a place on the second cycle}

In the second cycle, students are given the choice of an incomplete clever friend who is idolized to become peer tutors. Students who are willing to be appointed to guide his friend asked if incomplete. If there is an agreement then they became teammates who are successful or not depends on their cooperation.

Students who are good to feel appreciated and tried to guide his friend who did not complete for its ability to increase and eventually got better grades and thorough.

\section{The development of Descriptive Monologue Speaking Ability}

Table 10

Descriptive Monologue Speaking Ability Level in Cycle I and Cycle II

\begin{tabular}{cccc}
\hline Interval Class & Frequency Cycle I & Frequency Cycle II & Summary \\
\hline $90-100$ & 4 & 5 & $\mathrm{Up}$ \\
$77-89$ & 15 & 24 & $\mathrm{Up}$ \\
$65-78$ & 15 & 9 & \\
$53-64$ & 6 & 2 & \\
$41-52$ & 0 & 0 & \\
\hline Total & $\mathbf{4 0}$ & $\mathbf{4 0}$ & \\
\hline
\end{tabular}




\section{Development of the average value and the level of thoroughness}

Table 11

Average values and thoroughness Student in cycle I and cycle II

\begin{tabular}{clccc}
\hline No. & \multicolumn{1}{c}{ The elements } & Cycle I & Cycle II & Summary \\
\hline 1. & The average value & 76,7 & 79,9 & Up \\
\hline 2. & Level of thoroughness learning & 34 & 38 & UP \\
\hline
\end{tabular}

Based on analysis of data on the development of speaking skills (speaking) descriptive monologue using puppets in the media cycle I and cycle II it can be concluded that the ability of students in grade VII.5 SMP 4 Waru increased.

\section{Discussion}

Based on preliminary observations made by researchers in the classroom during the learning process the data obtained and the conditions of learning problems that occur at grade VII.5 SMP 4 Waru is most difficult to speak the English language (speaking), so it takes a media learning can improve their ability to speak.

Based on existing conditions, then this action research plan for learning to speak in descriptive monologues is used by the original media. This is done by the researcher that the students interested and motivated in learning and learning outcomes of students grade VII.5 SMP 4 Waru will increase.

Learning to speak monologues descriptive emphasis on active student activities, creativity, and skills in a focused attitude of an object or text to be discussed or presented in class with attention to issues of content, pronunciation, fluency, appearance, and creativity. In the preliminary stages of research trying to spark the curiosity of students through active discussion between teachers and students, pupils and students on matters relating to descriptive monologue, and as a facilitator is a good teacher and student (peer tutors). While consolidating all of the ideas developed by students are discussed, clarified, and integrated. The results are used as a feedback discussion and descriptive monologue tasks students are prepared to present in a monologue spoken text (individual) to determine the ability of each student.

\section{Cycle I}

In cycle I on some students still looked doubtful, so the learning process is hindered and takes a long time to explain things that are still in doubt.

The next stage of teachers to form groups within each group-group there is a good student peer tutor. Through peer, tutors expected students who still have doubts can ask freely to their smarter friends. Based on this observation, the students presented a descriptive monologue is still in doubt, although there are students who can look good and confident. This is evidenced in the cycle I am not completed by 10 students or $25 \%$, and students who complete 30 or $75 \%$. These data indicate that the cycle I did not complete in the classical style as the standard set was $85 \%$.

\section{CONCLUSION}

Based on the results of the study on Class Action Research can find out that the results of the data analysis above, research showed an increase in the grades of its main students at the "highly competitive" level which was initially $2.5 \%$ to $5 \%$, and at the level "from $40 \%$ to $42.5 \%$ and there was a decrease in low tilapia which was initially $27.5 \%$ to $7.5 \%$. This can reinforce the importance of the use of puppet media in improving grades and motivating 
students. So, variable research such as combining puppet media with other media will be better. And strengthening of data analysis to improve the evidence of research to convince the reader by results of the research.

\section{REFERENCES}

Bakhsh, S. (2016). Using Games as a Tool in Teaching Vocabulary to Young Learners. English Language Teaching 9(7): 120-127.

Bhima, S. (2019). Improving Speaking Skill By Using Fingers Puppet As Media at Second Grade of SMP PMDS Putri Palopo [Unpublished Master Thesis]. English Study Program: State Islamic Institute of Palopo.

Blatner, A. (2009, July 15). Role Playing in Education. Retrieved September 20, 2012, from http://www.blatner.com/adam/pdntbk/rlplayedu.html.

Brown, H. (2001). Teaching by Principles: An Interactive Approach to Language Pedagogy (Second Edition). New York: Pearson Education.

Dwi, N. (2014). The Use of Some Term of 'Chaotic Ages' Online Game As The Slang of Gamers [Unpublished master thesis]. English Education Department: STKIP PGRI Sidoarjo.

Dwi, N. (2018). A Comparative Analysis Between Personal Pronouns In English And Madura Language [Unpublished master thesis]. English Education Department: University of Islam Malang.

Harmer, J. (2007). How to Teach English. Harlow: Pearson Education Limited.

Hasanah, Y. (2019). Implementasi Strategi Bermain Peran Dengan Stik Boneka Untuk Meningkatkan Kreativitas Dan Kemampuan Berbicara Bahasa Inggris. realita, 17: 5973.

Hayatun, F. (2018). Improving Students' Speaking Skill and Motivation By Using Hand Puppets Show Media. English Education Journal, 9: 216-28.

Koshy, V. (2005). Action for improving practice. London: SAGE Publishing, Inc.

Made, S. (2019). Penerapan Metode Bercerita Menggunakan Boneka Tangan Untuk Meningkatkan Kemampuan Berbicara Anak Usia Dini. Realita 4: 648-53.

Nuruzzakaria, D. (2016). Meningkatkan Kemampuan Berbicara Anak Melalui Metode Bercerita Dengan Media Boneka Jari Pada Kelompok A Di Ra Miftahul Ulum Suren Ledokombo Tahun Pelajaran 2015/2016 [Skripsi tidak ditertibkan]. Pendidikan Bahasa Inggris:Universitas Muhammadiyah Jember.

Peristiwandari, P. (2012). Pengaruh Penerapan Media Boneka Tangan Terhadap Keterampilan Bercakap-Cakap Bahasa Mandarin Siswa Kelas 2 Sd Godwins School Surabaya. Jurnal CLYPTRA 1: 1-7.

Setiawati. (2016). Using Puppet As Media To Increase the Children Vocabulary." Jurnal Pendidikan 8(2): 257-69.

Tamah, S. (2011). Jigsaw Technique In Reading Class Of Young Learners: Revealing Students' Interaction [Unpublished Master Thesis]. English Education Department: Widya Mandala Catholic University.

Yolanda, D., \& Hadi, M. (2019). Using Puppet Games in Teaching Speaking for Tenth Graders of Senior High School. English Language in Focus (ELIF) 2(1): 1-10. 